HETEROCYCLES, Vol. 97, No. 1, 2018, pp. 395 - 408. @ 2018 The Japan Institute of Heterocyclic Chemistry Received, 29th January, 2018, Accepted, 21st February, 2018, Published online, 23rd February, 2018 DOI: $10.3987 / C O M-18-S(T) 27$

\title{
OXIDATIVE REARRANGEMENT OF BENZYLAMINES TO 4H-3,1-BENZOXAZINES VIA Cu/Mn-PROMOTED INTRAMOLECULAR C-H AMINATION/ELECTROCYCLIC REACTION CASCADE
}

\section{Chiaki Yamamoto, Kazutaka Takamatsu, Koji Hirano,* and Masahiro Miura*}

Department of Applied Chemistry, Graduate School of Engineering, Osaka University, Suita, Osaka 565-0871, Japan. e-mail: k_hirano@chem.eng.osaka-u.ac.jp; miura@chem.eng.osaka-u.ac.jp

\begin{abstract}
We have developed a copper/manganese-mediated oxidative rearrangement of benzylamines to $4 H-3,1$-benzoxazines of potent interest in medicinal applications. The reaction proceeds uniquely through the initial copper/manganese-promoted intramolecular $\mathrm{C}-\mathrm{H}$ amination giving benzazetidine intermediates and subsequent $4 \pi$ electrocyclic ring opening $/ 6 \pi$ electrocyclic ring closing cascade. The key to success is the introduction of picolinamide-based $N, N$-bidentate directing group. The obtained benzoxazines can also be readily hydrolyzed to the corresponding 2-aminobenzyl alcohols, thus indicating that the overall transformations is regarded as the ortho-aminative rearrangement of benzylamines to benzylic alcohols.
\end{abstract}

\section{INTRODUCTION}

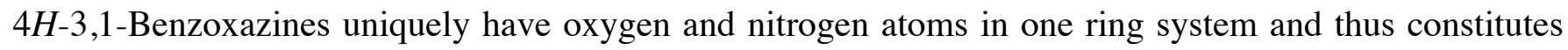
an important class of heterocycles in various fields of organic chemistry. They are frequently occurring in pharmaceutical agents, bioactive molecules, and natural products. ${ }^{1}$ Thus, synthetic chemists have developed numerous methodologies for the construction of benzoxazine framework. ${ }^{2}$ However, most reported procedures rely on ortho-functionalized aniline derivatives as the starting substrates, which are often tedious and difficult to prepare. ${ }^{3}$ On the other hand, the copper-mediated oxidative cyclization via $\mathrm{C}-\mathrm{H}$ cleavage now receives significant attention in heterocycle synthesis because it can allow simpler starting materials to be adopted in the cyclization event and thus can be more atom- and step-economical than conventional protocols. ${ }^{4}$ Our group also focused on the unique activity of less toxic, stable, and

The paper is dedicated to Prof. Kiyoshi Tomioka on the occasion of his 70th birthday. 
abundant copper salts and developed several copper-promoted intramolecular $\mathrm{C}-\mathrm{H}$ amination reactions for the synthesis of $N$-heterocycles including carbazoles, ${ }^{5 \mathrm{a}}$ indolines, ${ }^{5 \mathrm{~b}}$ isoindolinones,${ }^{5 \mathrm{c}}$ indoles, and oxazoles. $^{5 \mathrm{~d}}$ During our continuous interest in this chemistry, we next investigated the reactivity of benzylamines under copper-mediated $\mathrm{C}-\mathrm{H}$ activation conditions and serendipitously found the formation of 4H-3,1-benzoxazines via unique intramolecular $\mathrm{C}-\mathrm{H}$ amination/electrocyclic reaction sequence (Scheme 1). This cascade reaction can provide the benzoxazine from the simpler and easily available mono-substituted benzylamine derivative. A related palladium-catalyzed benzazetidine formation was already developed, ${ }^{6}$ but such a sequential reaction is not trivial, to the best of our knowledge. The detailed optimization studies and substrate scope are thus reported herein.<smiles>[R7]C(=O)NC([R7])c1c[R1]ccc1[2H]</smiles>

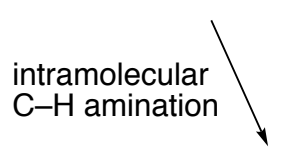<smiles></smiles>

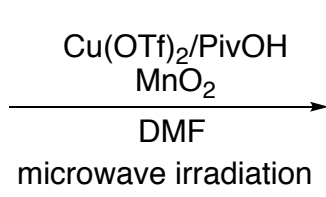

microwave irradiation<smiles>[Y7]C1=NC2=C([CH-][Se]C=C2)C([R7])O1</smiles>
$6 \pi$ electrocyclic ring closing

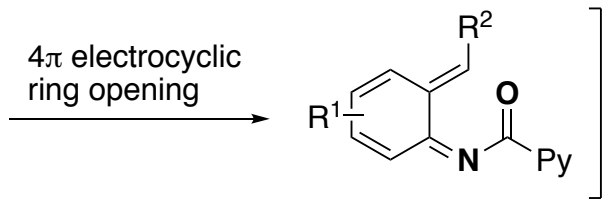

Scheme 1. Oxidative rearrangement of benzylamines to benzoxazines via $\mathrm{Cu} / \mathrm{Mn}$-mediated intramolecular C-H amination/electrocyclic reaction sequence (this work). Py =2-pyridyl.

\section{RESULTS AND DISCUSSION}

Our optimization studies commenced with the $N$-picolinoylbenzylamine derivative 1a, which is the representative $N, N$-bidentately coordinating substrate and originally developed by Daugulis. ${ }^{7}$ We first found that treatment of $\mathbf{1 a}$ with a $\mathrm{Cu}(\mathrm{OAc})_{2}$ catalyst $(20 \mathrm{~mol} \%)$ and an $\mathrm{MnO}_{2}$ oxidant (2.0 equiv) in $\mathrm{DMF}$ $(1.0 \mathrm{~mL})$ under microwave irradiation $\left(180{ }^{\circ} \mathrm{C}, 1 \mathrm{~h}\right)$ afforded the oxidatively and uniquely rearranged 2-pyridyl-4H-3,1-benzoxazine 2a in 29\% ${ }^{1} \mathrm{H}$ NMR yield (Table 1, entry 1). Such a pyridine-substituted oxazine is the promising ligand framework for metal catalysts. ${ }^{8}$ Screening of several acidic additives (100 mol\%) revealed that PivOH increased the conversion (entries 2-4). Notably, the choice of copper salts was critical; $\mathrm{Cu}(\mathrm{OTf})_{2}$ improved the ${ }^{1} \mathrm{H}$ NMR yield to $48 \%$ (entry 5 ) whereas acetate-type $\mathrm{Cu}(\mathrm{OPiv})_{2}$ and $\mathrm{Cu}(\mathrm{eh})_{2}$ (eh = 2-ethylhexanoate) as well as $\mathrm{Cu}\left(\mathrm{BF}_{4}\right)_{2}$ resulted in lower efficiency (entries 6-8). Subsequent fine tuning about amounts of catalyst, additive, and solvent (entries 9-12) identified a combination of $80 \mathrm{~mol} \% \mathrm{Cu}(\mathrm{OTf})_{2}, 50 \mathrm{~mol} \% \mathrm{PivOH}$, and $0.60 \mathrm{~mL}$ DMF to be optimal, giving 2a in $68 \%$ isolated yield (entry 12). The reaction was quite clean, and mass balance was almost perfect; unreactive 1a was recovered in $30 \%{ }^{1} \mathrm{H}$ NMR yield under conditions of entry 12 . Even with 100 mol\% of 
$\mathrm{Cu}(\mathrm{OAc})_{2}$, the yield of $\mathbf{2 a}$ was much lower (entry 13), and $\mathrm{Cu}(\mathrm{OTf})_{2}$ was thus confirmed to be superior. Additional several observations are to be noted: either $\mathrm{Cu}(\mathrm{OTf})_{2}$ or $\mathrm{MnO}_{2}$ alone did not promote the present transformation at all (entries 14 and 15); the corresponding $N$-benzoylbenzylamine showed no reactivity under identical conditions (data not shown), thus indicating necessity of cooper/manganese cooperation and $N, N$-bidentate coordination nature of $\mathbf{1 a}$.

Table 1. Optimization studies for copper/manganese-mediated oxidative rearrangement of $N$-picolinoylbenzylamine 1a to $4 H$-3,1-benzoxazine $\mathbf{2 a}^{\mathbf{a}}$<smiles>Cc1ccccc1C(C)NC(=O)c1ccccn1</smiles>

$1 \mathrm{a}$

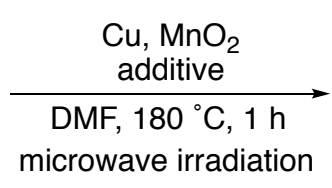

microwave irradiation<smiles>Cc1cccc2c1C(C)OC(c1ccccn1)=N2</smiles>

2

\begin{tabular}{|c|c|c|c|}
\hline entry & $\mathrm{Cu}(\mathrm{mol} \%)$ & additive (mol\%) & yield of $\mathbf{2 a}(\%)^{b}$ \\
\hline 1 & $\mathrm{Cu}(\mathrm{OAc})_{2}(20)$ & none & 29 \\
\hline 2 & $\mathrm{Cu}(\mathrm{OAc})_{2}(20)$ & $\mathrm{AcOH}(100)$ & 31 \\
\hline 3 & $\mathrm{Cu}(\mathrm{OAc})_{2}(20)$ & 1-AdCOOH (100) & 28 \\
\hline 4 & $\mathrm{Cu}(\mathrm{OAc})_{2}(20)$ & PivOH (100) & 37 \\
\hline 5 & $\mathrm{Cu}(\mathrm{OTf})_{2}(20)$ & PivOH (100) & 48 \\
\hline 6 & $\mathrm{Cu}\left(\mathrm{BF}_{4}\right)_{2}(20)$ & PivOH (100) & 23 \\
\hline 7 & $\mathrm{Cu}(\mathrm{OPiv})_{2}(20)$ & PivOH (100) & 23 \\
\hline 8 & $\mathrm{Cu}(\mathrm{eh})_{2}(20)$ & PivOH (100) & 26 \\
\hline 9 & $\mathrm{Cu}(\mathrm{OTf})_{2}(100)$ & PivOH (100) & 61 \\
\hline 10 & $\mathrm{Cu}(\mathrm{OTf})_{2}(100)$ & PivOH (50) & 64 \\
\hline $11^{\mathrm{c}}$ & $\mathrm{Cu}(\mathrm{OTf})_{2}(100)$ & PivOH (50) & 68 \\
\hline $12^{\mathrm{c}}$ & $\mathrm{Cu}(\mathrm{OTf})_{2}(80)$ & PivOH (50) & $70(68)$ \\
\hline $13^{\mathrm{c}}$ & $\mathrm{Cu}(\mathrm{OAc})_{2}(100)$ & PivOH (50) & 40 \\
\hline $14^{\mathrm{d}}$ & $\mathrm{Cu}(\mathrm{OTf})_{2}(100)$ & PivOH (100) & 0 \\
\hline 15 & none & PivOH (100) & 0 \\
\hline
\end{tabular}

${ }^{a}$ Conditions: 1a $(0.10 \mathrm{mmol}), \mathrm{Cu}, \mathrm{MnO}_{2}(0.40 \mathrm{mmol})$, additives, $\mathrm{DMF}(1.0 \mathrm{~mL})$, microwave irradiation, $1 \mathrm{~h}, \mathrm{~N}_{2}$. ${ }^{\mathrm{b}}$ Yields are estimated by ${ }^{1} \mathrm{H}$ NMR. Isolated yield is in parentheses. ${ }^{\mathrm{c}}$ In DMF $(0.60 \mathrm{~mL})$. ${ }^{\mathrm{d}}$ Without $\mathrm{MnO}_{2}$.

Under the conditions of entry 12 in Table 1, we investigated the scope and limitations of benzylamine derivatives 1 (Scheme 2). 


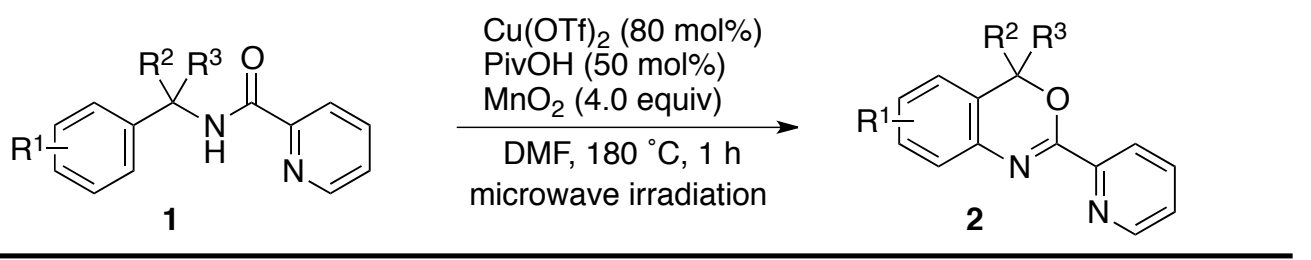

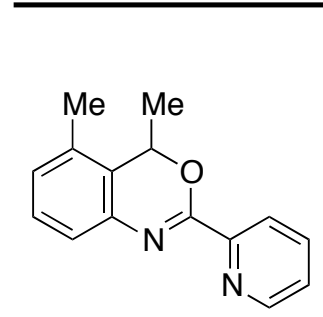

2a $70 \%(68 \%)$<smiles>CC1OC(c2ccccn2)=Nc2ccccc21</smiles>

2e $21 \%$<smiles>Cc1cccc2c1C(C)(C)OC(c1ccccn1)=N2</smiles>

2i $30 \%(26 \%)$<smiles>Cc1cccc(C2OC(c3ccccn3)=Nc3ccc(C)cc32)c1</smiles>

2m $38 \%(38 \%)$<smiles>COc1ccc(C2OC(c3ccccn3)=Nc3cc(OC)ccc32)cc1</smiles><smiles>Cc1ccc(-c2cccc3c2C(C)OC(c2ccccn2)=N3)cc1</smiles>

2b $57 \%(57 \%)$<smiles>c1ccc(C2=Nc3ccccc3CO2)nc1</smiles>

2f trace<smiles>c1ccc(C2=Nc3ccccc3C(c3ccccc3)(c3ccccc3)O2)cc1</smiles>

2j $95 \%(68 \%)$<smiles>CC1OC(c2ccccn2)=Nc2cccc(C(F)(F)F)c21</smiles>

2c $66 \%(62 \%)$<smiles>Cc1cc(Br)cc2c1C(C)OC(c1ccccn1)=N2</smiles>

2d $50 \%(46 \%)$<smiles>Cc1cccc2c1COC(c1ccccn1)=N2</smiles>

2g trace<smiles>c1ccc(C2OC(c3ccccn3)=Nc3ccccc32)cc1</smiles>

2k $43 \%(36 \%)$<smiles>CC1(C)OC(c2ccccn2)=Nc2ccccc21</smiles>

2h $49 \%$ (43\%)<smiles>Cc1ccccc1C1OC(c2ccccn2)=Nc2cccc(C)c21</smiles>

2I $82 \%(73 \%)$<smiles>Cc1ccc(C2OC(c3ccccn3)=Nc3cc(C)ccc32)cc1</smiles><smiles>CC(C)(C)c1ccc(C2OC(c3ccccn3)=Nc3cc(C(C)(C)C)ccc32)cc1</smiles>

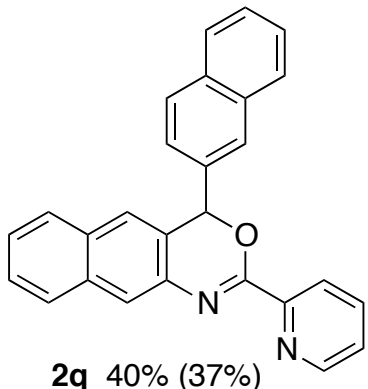

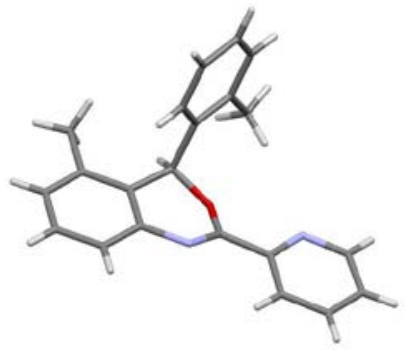

crystal structure of $\mathbf{2}$ |

Scheme 2. Copper/manganese-mediated oxidative rearrangement of $N$-picolinoylbenzylamines 1 to 4H-3,1-benzoxazines 2. $\quad{ }^{1} \mathrm{H}$ NMR yields are shown. Isolated yields are in parentheses.

The substrates that bear 4-methylphenyl and trifluoromethyl groups at the ortho position also underwent the reaction to afford the corresponding oxazines $\mathbf{2 b}$ and $\mathbf{2 c}$ in $57 \%$ and $62 \%$ isolated yields, respectively. 
The conditions were compatible with the aryl-Br functional group, which can be a useful synthetic handle for further elaborations (2d). The ortho substituent apparently gave positive effects on reaction efficiency; the parent benzylamine 1e resulted in lower conversion (2e), thus suggesting the important Thorpe-Ingold effect ${ }^{9}$ in the $\mathrm{C}-\mathrm{H}$ activation step (vide infra). Similar steric effects were observed with respect to the substitution pattern at the benzylic position $\alpha$ to nitrogen; the reaction of simple benzylamines $\mathbf{1 f}$ and $\mathbf{1 g}$ were sluggish (2f and $\mathbf{2 g}$ ) while tertiary benzyl-substituted $\mathbf{1 h}, \mathbf{1 i}$, and $\mathbf{1} \mathbf{j}$ showed better reactivity $(\mathbf{2} \mathbf{h}, \mathbf{2} \mathbf{i}$, and $\mathbf{2} \mathbf{j}$ ). However, we have no explanation for the reason why the yield of $\mathbf{2 i}$ was lower than that of $\mathbf{2 h}$. Additional investigation was performed with the diarylmethylamine structural motif. The reaction of diphenylmethylamine $\mathbf{1 k}$ delivered the desired product $\mathbf{2 k}$ in a moderate yield. Also in this case, sterically demanding substrates were more promising: the yield increased in order of ortho- $>$ meta- $>$ para-substituted diarylmethylamines (21, 2m, 2n, and 20 ). Additionally, in the meta-substituted $\mathbf{1 m}$, more sterically accessible $\mathrm{C}-\mathrm{H}$ was selectively functionalized. Unfortunately, the electron-donating methoxy group was detrimental (2p), but higher $\pi$-extended naphthoxazine 2q was accessible under the standard conditions. Notably, the 4H-3,1-benzoxazine structure of $\mathbf{2 l}$ was unambiguously confirmed by single-crystal X-ray diffraction. ${ }^{10}$

The obtained 4H-3,1-benzoxazines $\mathbf{2 a}$ and $\mathbf{2 l}$ could be readily hydrolyzed into the corresponding 2-aminobenzyl alcohols $\mathbf{3 a}$ and $\mathbf{3 1}$ in good yields (Scheme 3). The product 3a was known compound, and its spectra data was in agreement with the reported values. ${ }^{11}$ On the other hand, the structure of $\mathbf{3 1}$ was determined by ${ }^{1} \mathrm{H}$ NMR, ${ }^{13} \mathrm{C}$ NMR, HRMS, and finally X-ray analysis. ${ }^{10}$ Thus, the overall transformation can be regarded as the ortho-aminative rearrangement of benzylamines to benzyl alcohols.
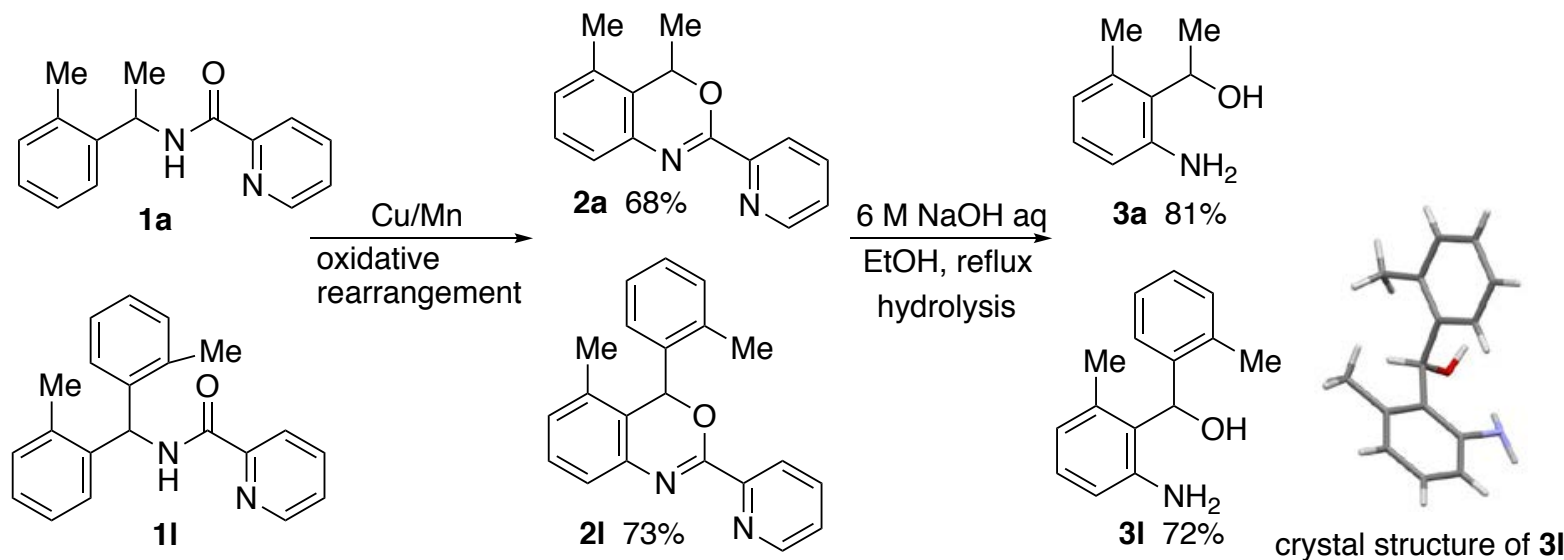

Scheme 3. The overall transformation of benzylamines 1a and $\mathbf{1 l}$ to 2-aminobenzyl alcohols $\mathbf{3 a}$ and $\mathbf{3 1}$ via $\mathrm{Cu} / \mathrm{Mn}$-mediated oxidative rearrangement and hydrolysis. Isolated yields are given. 
On the basis of the literature information, we propose the reaction mechanism of $1 \mathbf{a}$ as shown in Scheme 4. An initial $N, N$-bidentate coordination of $N$-picolinoylbenzylamine 1a to $\mathrm{CuX}_{2} 4$ with the liberation of $\mathrm{HX}$ forms the chelated $\mathrm{Cu}$ species 5 . Subsequent $\mathrm{C}-\mathrm{H}$ cupration generates the metalacycle $\mathbf{6}$, which can be sterically accelerated by the substituents at the ortho and benzylic positions (Thorpe-Ingold effect). The 4-membered benzazetidine intermediate $\mathbf{8}$ follows from the oxidation (disproportionation)-induced reductive elimination via $\mathrm{Cu}(\mathrm{III})$ 7. ${ }^{12}$ The higher oxidation state of $\mathrm{Cu}(\mathrm{III}) 7$ enables such a challenging, small ring-constructing reductive elimination. As mentioned in the introduction part, the related process was recently developed under Pd(II) catalysis by Chen and coworkers. ${ }^{6}$ The formed benzazetidine 8 then undergoes thermal $4 \pi$ electrocyclic ring opening $/ 6 \pi$ electrocyclic ring closing cascade to furnish the observed 4H-3,1-benzoxazine $\mathbf{2 a} .^{6,13}$ If the concurrently formed $\mathrm{Cu}(\mathrm{I})$ species 9 was reoxidized with $\mathrm{MnO}_{2}$ to the starting $\mathrm{CuX}_{2} 4$, the copper catalytic cycle could be completed. However, the product, 2-pyridyl-3,1-oxazine 2a, can be a good ligand to copper and thus retard the catalytic turnover due to its tight coordination. ${ }^{14}$

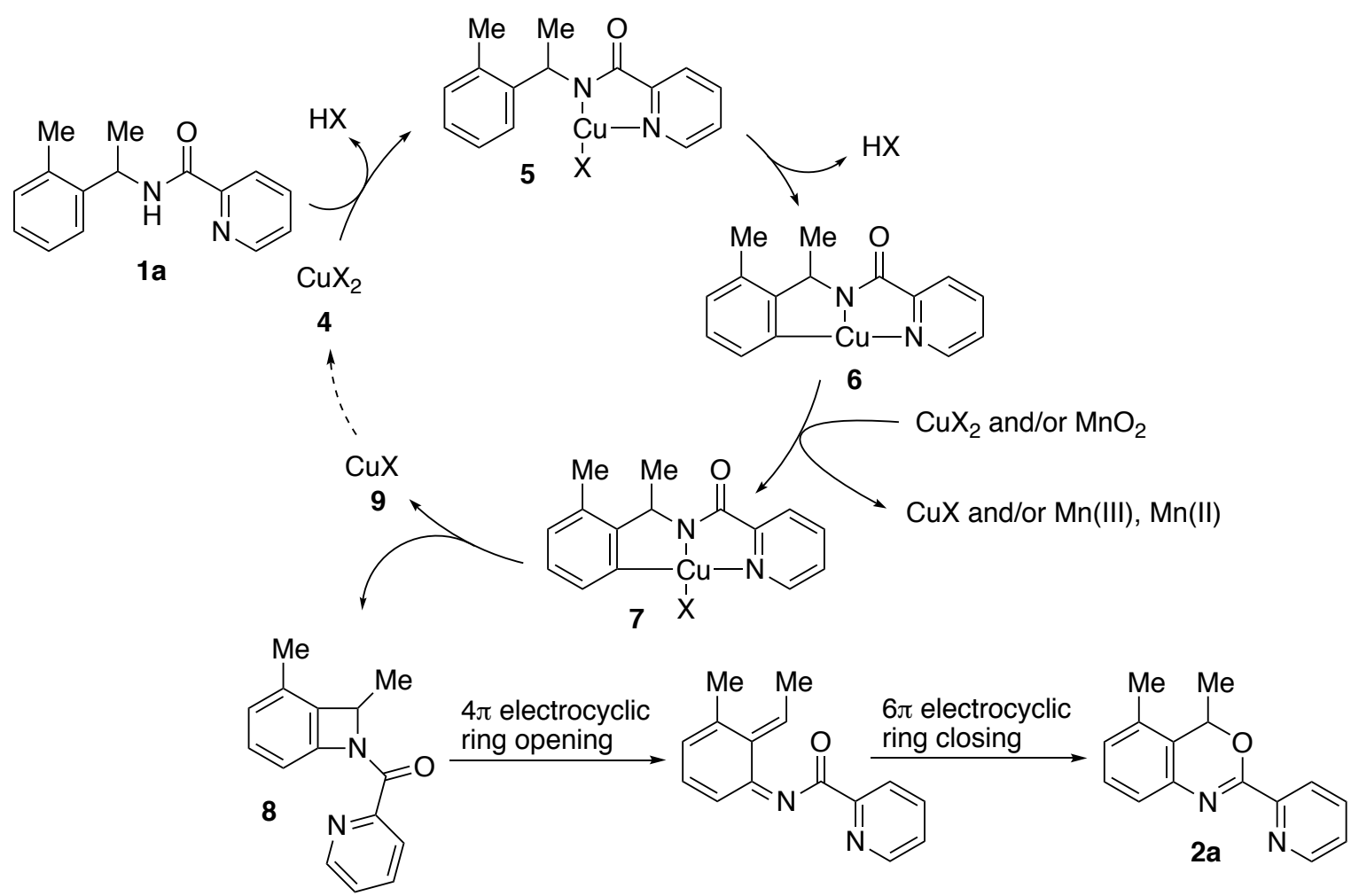

Scheme 4. Plausible mechanism of oxidative rearrangement of $N$-picolinoylbenzylamine 1a to 4H-3,1-benzoxazine 2a. X $=$ OTf or OPiv.

Previously, we $\mathrm{e}^{15}$ and Wang and coworkers ${ }^{16}$ reported related copper-promoted reactions of benzylamines through the benzazetidine intermediate $\mathbf{8}$, in which $N$-centered radical species was believed to take part in the 4-membered ring construction. To determine whether a similar radical species is involved or not in the present case, we conducted control experiments with radical inhibitors (Scheme 5a). The yield of $2 \mathbf{a}$ 
decreased, but the reaction was not completely shut down. Additionally, a primary kinetic isotope effect (KIE) value of $k_{\mathrm{H}} / k_{\mathrm{D}}=1.7$ was observed in the parallel reaction of $\mathbf{1} \mathbf{j}$ and $\mathbf{1} \mathbf{j}-\boldsymbol{d}_{\mathbf{1 5}}$ (Scheme $\left.5 \mathrm{~b}\right){ }^{17} \quad$ These outcomes support the organometallic pathway involving the rate-limiting $\mathrm{C}-\mathrm{H}$ cupration proposed in Scheme 4, rather than the reported radical pathway. Although the detailed C-H cupration mechanism $(5$ to 6 in Scheme 4) still remains unclear, the electrophilic metalation pathway ${ }^{18}$ is likely, which can explain the higher performance with $\mathrm{Cu}(\mathrm{OTf})_{2}$ of cationic nature. Actually, the unsymmetrical diarylmethylamine substrate $\mathbf{1 r}$ underwent the reaction preferably at the more electron-rich $t$-Bu-substituted benzene ring (Scheme 5c).

a) effects of radical inhibitors

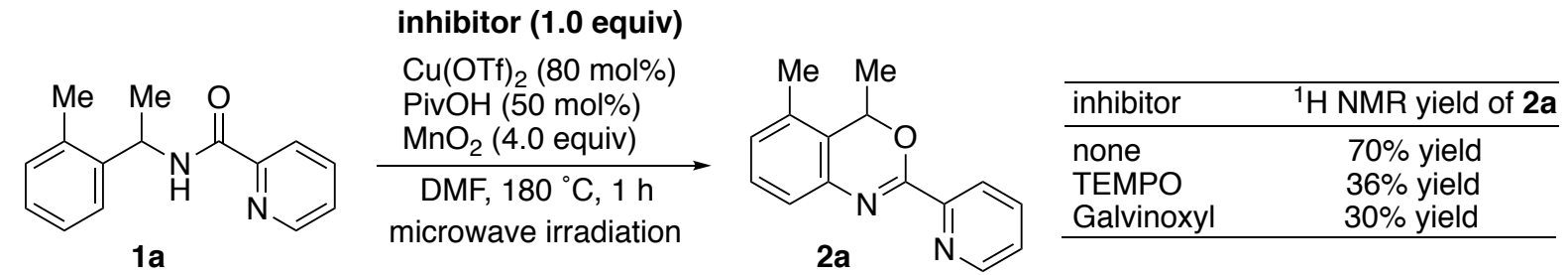

b) KIE experiment<smiles>O=C(NC(c1ccccc1)(c1ccccc1)c1ccccc1)c1ccccn1</smiles>

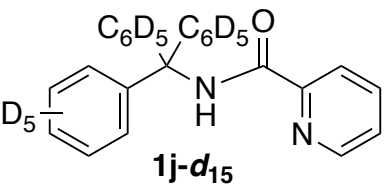

$\mathrm{Cu}(\mathrm{OTf})_{2}(80 \mathrm{~mol} \%)$ $\mathrm{PivOH}(50 \mathrm{~mol} \%)$ $\underset{\mathrm{MnO}_{2} \text { (4.0 equiv) }}{\mathrm{DMF} 150{ }^{\circ} \mathrm{C}, 12 \mathrm{~min}}$ oil bath parallel $k_{\mathrm{H}} / k_{\mathrm{D}}=1.7$<smiles>c1ccc(C2=Nc3ccccc3C(c3ccccc3)(c3ccccc3)O2)cc1</smiles><smiles>[13CH3][13CH3]</smiles><smiles>[2H][13c]1ccc2c(c1)N=C(c1ccccn1)OC2(C)C</smiles>

c) reaction of unsymmetrical diarylmethylamine substrate $\mathbf{1 r}$<smiles>CC(C)(C)c1ccc(C(NC(=O)c2ccccn2)c2ccc(C(F)(F)F)cc2)cc1</smiles>

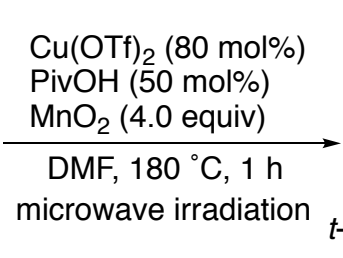<smiles>CC(C)(C)c1ccc2c(c1)N=C(c1ccccn1)OC2c1ccc(C(F)(F)F)cc1</smiles><smiles>CC(C)(C)c1ccc(C2OC(c3ccccn3)=Nc3cc(C(F)(F)F)ccc32)cc1</smiles>

$20 \%, 2 r / 2 r^{\prime}=85: 15$

Scheme 5. Experiments for mechanistic considerations

\section{CONCLUSION}

We have developed a unique oxidative rearrangement of benzylamines to $4 H-3,1$-benzoxazines via picolinamide-directed, copper/manganese-promoted intramolecular $\mathrm{C}-\mathrm{H}$ amination/electrocyclic reaction cascade. The obtained benzoxazines are among representative $N$-heterocycles of potent interest in 
medicinal and pharmaceutical chemistry. Additionally, subsequent hydrolysis forms the corresponding 2-aminobenzyl alcohols; the overall transformation thus can be regarded as ortho-aminative rearrangement of benzylamines to benzyl alcohols. While still limited in scope, this protocol can provide an additional approach to otherwise synthetically challenging $N$-heterocycles and new insight to further development and design of $\mathrm{C}-\mathrm{H}$ activation catalysis based on copper.

\section{EXPERIMENTAL}

General. ${ }^{1} \mathrm{H},{ }^{13} \mathrm{C}\left\{{ }^{1} \mathrm{H}\right\}$, and ${ }^{19} \mathrm{~F}\left\{{ }^{1} \mathrm{H}\right\}$ NMR spectra were recorded at 400, 100, and $376 \mathrm{MHz}$, respectively, for $\mathrm{CDCl}_{3}$ solutions. HRMS data were obtained by APCI using TOF. GC analysis was carried out using a silicon OV-17 column (i. d. $2.6 \mathrm{~mm}$ x $1.5 \mathrm{~m}$ ) or a CBP-1 capillary column (i. d. $0.5 \mathrm{~mm}$ x $25 \mathrm{~m}$ ). TLC analyses were performed on commercial glass plates bearing 0.25-mm layer of Merck Silica gel $60 \mathrm{~F}_{254}$. Silica gel (Wakosil C-200) was used for column chromatography. Microwave irradiation was conducted with Initiator ${ }^{+}$(Biotage), and the reaction temperature was measured by an internal probe. Unless otherwise noted, materials obtained from commercial suppliers were used as received. DMF was dried on a Glass Contour Solvent dispensing system (Nikko Hansen \& Co., Ltd.) prior to use. The starting $N$-picolinoylbenzylamines 1 were prepared from the corresponding primary amines and picolinoyl chloride. ${ }^{5 \mathrm{~b}} \quad$ The deuterium-labeled $\mathbf{1} \mathbf{j}-\boldsymbol{d}_{\mathbf{1 5}}$ was synthesized according to the following procedure.

Preparation of $\mathbf{1 j}-\boldsymbol{d}_{15} \cdot \quad n \mathrm{BuLi}(1.55 \mathrm{M}$ in hexanes, $20 \mathrm{~mL}, 32 \mathrm{mmol})$ was added at $-78{ }^{\circ} \mathrm{C}$ to a solution of bromobenzene- $d_{5}(3.2 \mathrm{~mL}, 30 \mathrm{mmol})$ in THF $(50 \mathrm{~mL})$, and the solution was stirred for $30 \mathrm{~min}$. Diethyl carbonate $(1.2 \mathrm{~mL}, 10 \mathrm{mmol})$ was added dropwise, and the resulting mixture was allowed to warm to room temperature and stirred for an additional $3 \mathrm{~h}$. The solution was then quenched with water and extracted three times with $\mathrm{CH}_{2} \mathrm{Cl}_{2}$. The combined organic layer was dried over $\mathrm{Na}_{2} \mathrm{SO}_{4}$. After concentration under reduced pressure, silica gel column purification with hexane/EtOAc $(20 / 1, \mathrm{v} / \mathrm{v})$ afforded tris(pentadeuteriophenyl)methanol (2.5 g, 90\% yield) as a white solid.

The obtained perdeuteriotriphenylmethanol was placed in a two-necked reaction flask with a reflux condenser, and the flask was flushed with nitrogen. Dry toluene $(6.0 \mathrm{~mL})$ was sequentially injected via a syringe. The mixture was heated to $80{ }^{\circ} \mathrm{C}$. Acetyl chloride $(640 \mu \mathrm{L}, 9.0 \mathrm{mmol})$ was added with a dropping funnel while stirring vigorously with a magnetic stirrer. Once the solid had dissolved, additional acetyl chloride $(960 \mu \mathrm{L}, 14 \mathrm{mmol})$ was added over $10 \mathrm{~min}$. The solution was heated for an additional $30 \mathrm{~min}$. After concentration under reduced pressure, choloro\{tris(pentadeuteriophenyl)\}methane was obtained, which was used for the next step without further purifications. 
The residual solid was placed in a two-necked reaction flask, and the flask was flushed with nitrogen. $\mathrm{CH}_{2} \mathrm{Cl}_{2}(14 \mathrm{~mL})$ and ammonia solution $(25 \%$ in water, $15 \mathrm{~mL})$ were sequentially injected via a syringe. The resulting solution was stirred for 2 days vigorously at room temperature. The solution was then extracted with $\mathrm{CH}_{2} \mathrm{Cl}_{2}$ and washed two times with water. The organic layer was dried over anhydrous $\mathrm{Na}_{2} \mathrm{SO}_{4}$. After concentration under reduced pressure, silica gel column purification with $\mathrm{CH}_{2} \mathrm{Cl}_{2}$ afforded tris(pentadeuteriophenyl)methylamine ( $2.2 \mathrm{~g}, 89 \%$ yield) as a white solid.

The obtained perdeuteriotriphenylmethylamine $(2.2 \mathrm{~g}, 8.1 \mathrm{mmol})$, pyridine-2-carbonyl chloride hydrochloride (1.4 g, $8.1 \mathrm{mmol}$ ), and $N, N$-dimethyl-4-aminopyridine (DMAP; $290 \mathrm{mg}, 2.4 \mathrm{mmol}$ ) were placed in a $50 \mathrm{~mL}$ two-necked reaction flask, and the flask was flushed with nitrogen. Anhydrous $\mathrm{CH}_{2} \mathrm{Cl}_{2}(16 \mathrm{~mL})$ and $\mathrm{Et}_{3} \mathrm{~N}(3.3 \mathrm{~mL}, 24 \mathrm{mmol})$ were added at $0{ }^{\circ} \mathrm{C}$, and the resulting solution was stirred at room temperature for $4 \mathrm{~h}$. The mixture was quenched with water $(30 \mathrm{~mL})$ and extracted three times with $\mathrm{CH}_{2} \mathrm{Cl}_{2}$. Combined organic phase was dried over anhydrous $\mathrm{Na}_{2} \mathrm{SO}_{4}$. After concentration under reduced pressure, silica gel column purification with hexane/EtOAc $(3 / 1, \mathrm{v} / \mathrm{v})$ afforded $N$-\{tris(pentadeuteriophenyl)methyl \}picolinamide $\left(\mathbf{1} \mathbf{j}-\boldsymbol{d}_{\mathbf{1 5}} ; 2.8 \mathrm{~g}, 7.4 \mathrm{mmol},>99 \% \mathrm{D}\right)$ in $91 \%$ yield.

\section{Copper/Manganese-promoted oxidative rearrangement of $N$-picolinoylbenzylamines 1 to}

$\mathbf{4 H - 3 , 1 - b e n z o x a z i n e s ~ 2 . ~ T h e ~ r e a c t i o n ~ o f ~} \mathbf{1 a}$ is representative (Table 1, entry 12). $\mathrm{Cu}(\mathrm{OTf})_{2}(29 \mathrm{mg}$, $0.080 \mathrm{mmol}), \mathrm{N}$-(1-(o-tolyl)ethyl)picolinamide $(1 \mathbf{a} ; 24 \mathrm{mg}, 0.10 \mathrm{mmol})$, pivalic acid $(5.1 \mathrm{mg}, 0.050$ $\mathrm{mmol}$ ), and $\mathrm{MnO}_{2}(35 \mathrm{mg}, 0.40 \mathrm{mmol})$ were placed in a microwave vessel, and the vessel was flushed with nitrogen. DMF $(0.60 \mathrm{~mL})$ was sequentially injected via a syringe. The mixture was irradiated under microwave reactor conditions at $180{ }^{\circ} \mathrm{C}$ for $1 \mathrm{~h}$. The resulting mixture was then quenched with water, and a small amount of ethylenediamine was added to dissolve the residual copper salts in the aqueous phase. The mixture was extracted with EtOAc three times, and the combined organic layer was dried over anhydrous $\mathrm{Na}_{2} \mathrm{SO}_{4}$. After concentration under reduced pressure, silica gel column purification with hexane/EtOAc (1/2, v/v) afforded 4,5-dimethyl-2-(pyridin-2-yl)-4H-benzo$[d][1,3]$ oxazine $(\mathbf{2 a} ; 16 \mathrm{mg}, 0.068 \mathrm{mmol})$ in $68 \%$ yield.

Hydrolysis of $\mathbf{4 H - 3 , 1 - b e n z o x a z i n e s ~ 2 . ~ T h e ~ r e a c t i o n ~ o f ~} \mathbf{2 a}$ is representative (Scheme 3, top). 4,5-Dimethyl-2-(pyridin-2-yl)-4H-benzo[d][1,3]oxazine (2a; $29 \mathrm{mg}, 0.12 \mathrm{mmol})$, EtOH (3 mL), and $6 \mathrm{M}$ aqueous $\mathrm{NaOH}(1 \mathrm{~mL})$ were placed in a $50 \mathrm{~mL}$ recovery flask equipped with a reflux condenser, and the flask was flushed with nitrogen. The resulting solution was stirred at $100{ }^{\circ} \mathrm{C}$ for $4 \mathrm{~h}$. The resulting mixture was diluted with water and extracted three times with EtOAc. The combined organic layer was dried over anhydrous $\mathrm{Na}_{2} \mathrm{SO}_{4}$. After concentration under reduced pressure, silica gel column purification with hexane/EtOAc (3/1, v/v) afforded 1-(2-amino-6-methylphenyl)ethan-1-ol (3a; 15 mg, 
$0.097 \mathrm{mmol}$ ) in $81 \%$ yield.

\section{Characterization Data for Products}

4,5-Dimethyl-2-(pyridin-2-yl)-4H-benzo[d] $[1,3]$ oxazine (2a) colorless liquid; $16 \mathrm{mg}(68 \%)$; IR (neat, $\mathrm{cm}^{-1}$ ) 1242, 1435, 1467, 1581, 1618; ${ }^{1} \mathrm{H}$ NMR (400 MHz, $\left.\mathrm{CDCl}_{3}\right) \delta 1.54$ (d, J=6.6 Hz, 3H), 2.27 (s, 3H), $5.77(\mathrm{q}, J=6.6 \mathrm{~Hz}, 1 \mathrm{H}), 7.06(\mathrm{~d}, J=7.6 \mathrm{~Hz}, 1 \mathrm{H}), 7.21-7.29(\mathrm{~m}, 2 \mathrm{H}), 7.40(\mathrm{ddd}, J=1.2,4.8,7.6 \mathrm{~Hz}, 1 \mathrm{H})$, $7.81(\mathrm{dt}, J=1.8,7.8 \mathrm{~Hz}, 1 \mathrm{H}), 8.25(\mathrm{td}, J=1.0,7.8 \mathrm{~Hz}, 1 \mathrm{H}), 8.78(\mathrm{ddd}, J=1.0,1.8,4.8 \mathrm{~Hz}, 1 \mathrm{H}) ;{ }^{13} \mathrm{C}\left\{{ }^{1} \mathrm{H}\right\}$ NMR (100 MHz, $\left.\mathrm{CDCl}_{3}\right) \delta$ 17.4, 21.0, 71.4, 123.5, 123.6, 125.3, 125.8, 128.3, 129.2, 132.1, 136.6, 138.1, 149.8, 150.8, 154.6; HRMS (APCI) $m / z\left([\mathrm{M}+\mathrm{H}]^{+}\right)$calcd for $\mathrm{C}_{15} \mathrm{H}_{15} \mathrm{~N}_{2} \mathrm{O}$ : 239.1179, found: 239.1180 .

4-Methyl-2-(pyridin-2-yl)-5-(p-tolyl)-4H-benzo[d][1,3]oxazine (2b) colorless liquid; $18 \mathrm{mg}(57 \%)$; IR (neat, $\left.\mathrm{cm}^{-1}\right)$ 1240, 1355, 1438, 1467, 1514, 1570, 1624; ${ }^{1} \mathrm{H}$ NMR (400 MHz, $\left.\mathrm{CDCl}_{3}\right) \delta 1.31(\mathrm{~d}, J=7.0 \mathrm{~Hz}$, 3H), $2.42(\mathrm{~s}, 3 \mathrm{H}), 5.78$ (q, $J=7.0 \mathrm{~Hz}, 1 \mathrm{H}), 7.11(\mathrm{dd}, J=1.3,7.6 \mathrm{~Hz}, 1 \mathrm{H}), 7.21-7.26(\mathrm{~m}, 4 \mathrm{H}), 7.33-7.45$ (m, 3H), $7.81(\mathrm{dt}, J=1.7,7.6 \mathrm{~Hz}, 1 \mathrm{H}), 8.22(\mathrm{td}, J=1.0,8.0 \mathrm{~Hz}, 1 \mathrm{H}), 8.78(\mathrm{ddd}, J=1.0,1.7,4.7 \mathrm{~Hz}, 1 \mathrm{H})$; ${ }^{13} \mathrm{C}\left\{{ }^{1} \mathrm{H}\right\}$ NMR $\left(100 \mathrm{MHz}, \mathrm{CDCl}_{3}\right) \delta 21.2,21.7,71.6,123.5,124.9,125.1,125.4,128.3,128.8,129.0$, 129.2, 136.3, 136.6, 137.2, 138.3, 138.5, 149.8, 150.7, 154.9; HRMS (APCI) $m / z\left([\mathrm{M}+\mathrm{H}]^{+}\right)$calcd for $\mathrm{C}_{21} \mathrm{H}_{19} \mathrm{~N}_{2} \mathrm{O}: 315.1492$, found: 315.1489 .

4-Methyl-2-(pyridin-2-yl)-5-(trifluoromethyl)-4H-benzo[d][1,3]oxazine (2c) white solid; mp 57.3-58.2 ${ }^{\circ} \mathrm{C} ; 18 \mathrm{mg}(62 \%)$; IR (neat, $\left.\mathrm{cm}^{-1}\right)$ 1271, 1323, 1421, 1587, 1618; ${ }^{1} \mathrm{H}$ NMR (400 MHz, $\left.\mathrm{CDCl}_{3}\right) \delta 1.58(\mathrm{~d}, J$ $=6.3 \mathrm{~Hz}, 3 \mathrm{H}), 6.00(\mathrm{q}, J=6.3 \mathrm{~Hz}, 1 \mathrm{H}), 7.44-7.46(\mathrm{~m}, 2 \mathrm{H}), 7.54(\mathrm{~d}, J=7.4 \mathrm{~Hz}, 1 \mathrm{H}), 7.64(\mathrm{~d}, J=7.8 \mathrm{~Hz}$, $1 \mathrm{H}), 7.85(\mathrm{dt}, J=1.7,7.8 \mathrm{~Hz}, 1 \mathrm{H}), 8.24(\mathrm{td}, J=1.0,8.0 \mathrm{~Hz}, 1 \mathrm{H}), 8.81$ (ddd, $J=1.0,1.7,4.7 \mathrm{~Hz}, 1 \mathrm{H})$; ${ }^{13} \mathrm{C}\left\{{ }^{1} \mathrm{H}\right\} \operatorname{NMR}\left(100 \mathrm{MHz}, \mathrm{CDCl}_{3}\right) \delta 21.2,70.8$ (q, $\left.J=2.3 \mathrm{~Hz}\right), 123.7,123.9$ (q, $\left.J=273.7 \mathrm{~Hz}\right), 124.4$ (q, $J$ $=5.6 \mathrm{~Hz}), 125.1(\mathrm{q}, J=31.4 \mathrm{~Hz}), 125.77$ (q, $J=1.5 \mathrm{~Hz}), 125.82,128.7,129.4,136.8,139.9,150.0,150.1$, 155.9; ${ }^{19} \mathrm{~F}\left\{{ }^{1} \mathrm{H}\right\}$ NMR (376 MHz, $\left.\mathrm{CDCl}_{3}\right) \delta-59.0$; HRMS (APCI) $m / z\left([\mathrm{M}+\mathrm{H}]^{+}\right)$calcd for $\mathrm{C}_{15} \mathrm{H}_{12} \mathrm{~F}_{3} \mathrm{~N}_{2} \mathrm{O}$ : 293.0896, found: 293.0902 .

7-Bromo-4,5-dimethyl-2-(pyridin-2-yl)-4H-benzo[d][1,3]oxazine (2d) colorless liquid; $15 \mathrm{mg}(46 \%)$; IR (neat, $\left.\mathrm{cm}^{-1}\right)$ 1263, 1309, 1359, 1436, 1465, 1566, 1585, 1620; ${ }^{1} \mathrm{H}$ NMR (400 MHz, CDCl $) \delta 1.52(\mathrm{~d}, J$ $=6.7 \mathrm{~Hz}, 3 \mathrm{H}), 2.25(\mathrm{~s}, 3 \mathrm{H}), 5.73(\mathrm{q}, J=6.7 \mathrm{~Hz}, 1 \mathrm{H}), 7.21-7.22(\mathrm{~m}, 1 \mathrm{H}), 7.40-7.44(\mathrm{~m}, 2 \mathrm{H}), 7.82(\mathrm{dt}, J=$ $1.8,7.8 \mathrm{~Hz}, 1 \mathrm{H}), 8.25(\mathrm{td}, J=0.9,7.8 \mathrm{~Hz}, 1 \mathrm{H}), 8.78(\mathrm{ddd}, J=0.9,1.8,4.8 \mathrm{~Hz}, 1 \mathrm{H}) ;{ }^{13} \mathrm{C}\left\{{ }^{1} \mathrm{H}\right\} \mathrm{NMR}(100$ $\left.\mathrm{MHz}_{\mathrm{CDCl}}\right) \delta 17.2,20.9,71.3,121.5,123.7,124.7,125.6,126.4,131.6,134.0,136.7,139.7,149.8$, 150.4, 155.6; HRMS (APCI) $m / z\left([\mathrm{M}+\mathrm{H}]^{+}\right)$calcd for $\mathrm{C}_{15} \mathrm{H}_{14} \mathrm{BrN}_{2} \mathrm{O}: 317.0284$, found: 317.0286 .

4,4-Dimethyl-2-(pyridin-2-yl)-4H-benzo[d][1,3]oxazine (2h) colorless liquid; $10 \mathrm{mg}$ (43\%); IR (neat, $\left.\mathrm{cm}^{-1}\right) 1271,1334,1365,1471,1481,1566,1598,1620 ;{ }^{1} \mathrm{H}$ NMR (400 MHz, $\left.\mathrm{CDCl}_{3}\right) \delta 1.76(\mathrm{~s}, 6 \mathrm{H}), 7.16$ $(\mathrm{dd}, J=1.4,7.5 \mathrm{~Hz}, 1 \mathrm{H}), 7.23(\mathrm{dt}, J=1.4,7.5 \mathrm{~Hz}, 1 \mathrm{H}), 7.31$ (dt, $J=1.4,7.5 \mathrm{~Hz}, 1 \mathrm{H}), 7.39$ (ddd, $J=1.1$, 4.8, $7.5 \mathrm{~Hz}, 1 \mathrm{H}), 7.44(\mathrm{dd}, J=1.2,7.8 \mathrm{~Hz}, 1 \mathrm{H}), 7.81(\mathrm{dt}, J=1.7,7.7 \mathrm{~Hz}, 1 \mathrm{H}), 8.20$ (td, $J=1.0,8.0 \mathrm{~Hz}$, 
1H), $8.81(\mathrm{ddd}, J=1.0,1.7,4.8 \mathrm{~Hz}, 1 \mathrm{H}) ;{ }^{13} \mathrm{C}\left\{{ }^{1} \mathrm{H}\right\}$ NMR $\left(100 \mathrm{MHz}, \mathrm{CDCl}_{3}\right) \delta$ 28.6, 79.1, 122.3, 123.4, 125.2, 125.9, 127.3, 128.6, 131.4, 136.6, 138.2, 149.9, 150.9, 155.4; HRMS (APCI) $m / z\left([\mathrm{M}+\mathrm{H}]^{+}\right)$calcd for $\mathrm{C}_{15} \mathrm{H}_{15} \mathrm{~N}_{2} \mathrm{O}$ : 239.1179, found: 239.1181 .

4,4,5-Trimethyl-2-(pyridin-2-yl)-4H-benzo[d][1,3]oxazine (2i) colorless liquid; $6.6 \mathrm{mg}$ (26\%); IR (neat, $\left.\mathrm{cm}^{-1}\right)$ 1240, 1273, 1334, 1429, 1465, 1566, 1633, 1691; ${ }^{1} \mathrm{H}$ NMR (400 MHz, $\left.\mathrm{CDCl}_{3}\right) \delta 1.84(\mathrm{~s}, 6 \mathrm{H}), 2.43$ (s, 3H), 7.03 (dd, $J=0.6,7.6 \mathrm{~Hz}, 1 \mathrm{H}), 7.19$ (t, $J=7.6 \mathrm{~Hz}, 1 \mathrm{H}), 7.33$ (dd, $J=0.8,7.6 \mathrm{~Hz}, 1 \mathrm{H}), 7.39$ (ddd, $J=1.2,4.8,7.6 \mathrm{~Hz}, 1 \mathrm{H}), 7.81(\mathrm{dt}, J=1.7,7.6 \mathrm{~Hz}, 1 \mathrm{H}), 8.18(\mathrm{td}, J=1.0,7.9 \mathrm{~Hz}, 1 \mathrm{H}), 8.81(\mathrm{ddd}, J=1.0$, 1.7, $4.8 \mathrm{~Hz}, 1 \mathrm{H}) ;{ }^{13} \mathrm{C}\left\{{ }^{1} \mathrm{H}\right\} \mathrm{NMR}\left(100 \mathrm{MHz}, \mathrm{CDCl}_{3}\right) \delta$ 22.5, 28.6, 80.4, 123.3, 124.9, 125.2, 128.1, 129.5, 131.2, 132.4, 136.6, 139.1, 149.9, 150.8, 154.7; HRMS (APCI) $m / z\left([\mathrm{M}+\mathrm{H}]^{+}\right)$calcd for $\mathrm{C}_{16} \mathrm{H}_{17} \mathrm{~N}_{2} \mathrm{O}$ : 253.1335, found: 253.1337 .

4,4-Diphenyl-2-(pyridin-2-yl)-4H-benzo[d][1,3]oxazine (2j) white solid; mp 212.0-213.9 ${ }^{\circ} \mathrm{C} ; 25 \mathrm{mg}$ (68\%); IR (neat, $\mathrm{cm}^{-1}$ ) 1271, 1327, 1421, 1570, 1618; ${ }^{1} \mathrm{H}$ NMR (400 MHz, $\left.\mathrm{CDCl}_{3}\right) \delta 6.75(\mathrm{dd}, J=1.3,7.7$ $\mathrm{Hz}, 1 \mathrm{H}), 7.19(\mathrm{dt}, J=1.3,7.7 \mathrm{~Hz}, 1 \mathrm{H}), 7.25-7.31(\mathrm{~m}, 10 \mathrm{H}), 7.34-7.41(\mathrm{~m}, 2 \mathrm{H}), 7.56(\mathrm{dd}, J=1.1,7.9 \mathrm{~Hz}$, $1 \mathrm{H}), 7.77(\mathrm{dt}, J=1.7,7.7 \mathrm{~Hz}, 1 \mathrm{H}), 8.22(\mathrm{td}, J=0.9,7.9 \mathrm{~Hz}, 1 \mathrm{H}), 8.78(\mathrm{ddd}, J=0.9,1.7,4.8 \mathrm{~Hz}, 1 \mathrm{H})$; ${ }^{13} \mathrm{C}\left\{{ }^{1} \mathrm{H}\right\} \mathrm{NMR}\left(100 \mathrm{MHz}, \mathrm{CDCl}_{3}\right) \delta 86.7,123.6,125.4,125.8,126.8,126.9,128.0,128.3,128.4,128.9$, 129.3, 136.7, 139.5, 142.6, 150.1, 150.4, 155.5; HRMS (APCI) $m / z\left([\mathrm{M}+\mathrm{H}]^{+}\right)$calcd for $\mathrm{C}_{25} \mathrm{H}_{19} \mathrm{~N}_{2} \mathrm{O}$ : 363.1492, found: 363.1493 .

4-Phenyl-2-(pyridin-2-yl)-4H-benzo[d $][\mathbf{1}, 3]$ oxazine (2k) colorless liquid; $10 \mathrm{mg}(36 \%)$; IR (neat, $\left.\mathrm{cm}^{-1}\right) 1263,1431,1450,1521,1685 ;{ }^{1} \mathrm{H}$ NMR (400 MHz, $\left.\mathrm{CDCl}_{3}\right) \delta 6.54(\mathrm{~s}, 1 \mathrm{H}), 6.87$ (d, $\left.J=7.4 \mathrm{~Hz}, 1 \mathrm{H}\right)$, $7.19(\mathrm{dt}, J=1.1,7.4 \mathrm{~Hz}, 1 \mathrm{H}), 7.33-7.42(\mathrm{~m}, 7 \mathrm{H}), 7.51(\mathrm{~d}, J=8.0 \mathrm{~Hz}, 1 \mathrm{H}), 7.77(\mathrm{dt}, J=1.7,7.7 \mathrm{~Hz}, 1 \mathrm{H})$, $8.15(\mathrm{~d}, J=8.0 \mathrm{~Hz}, 1 \mathrm{H}), 8.78(\mathrm{~d}, J=4.1 \mathrm{~Hz}, 1 \mathrm{H}) ;{ }^{13} \mathrm{C}\left\{{ }^{1} \mathrm{H}\right\} \mathrm{NMR}\left(100 \mathrm{MHz}, \mathrm{CDCl}_{3}\right) \delta 78.8,123.6,125.2$, 125.3, 125.4, 125.8, 127.3, 127.8, 128.8, 128.9, 129.2, 136.7, 138.8, 139.8, 150.0, 150.3, 155.3; HRMS (APCI) $m / z\left([\mathrm{M}+\mathrm{H}]^{+}\right)$calcd for $\mathrm{C}_{19} \mathrm{H}_{15} \mathrm{~N}_{2} \mathrm{O}: 287.1179$, found: 287.1181 .

5-Methyl-2-(pyridin-2-yl)-4-(o-tolyl)-4H-benzo[d][1,3]oxazine (2I) white solid; mp 186.6-187.9 ${ }^{\circ} \mathrm{C} ; 23$ mg (73\%); IR (neat, $\mathrm{cm}^{-1}$ ) 1263, 1350, 1465, 1558, 1579, 1616; ${ }^{1} \mathrm{H}$ NMR (400 MHz, $\left.\mathrm{CDCl}_{3}\right) \delta 2.00$ (s, 3H), $2.76(\mathrm{~s}, 3 \mathrm{H}), 6.73(\mathrm{~d}, J=7.5 \mathrm{~Hz}, 1 \mathrm{H}), 6.84(\mathrm{~s}, 1 \mathrm{H}), 6.99(\mathrm{t}, J=7.5 \mathrm{~Hz}, 1 \mathrm{H}), 7.08(\mathrm{~d}, J=7.5 \mathrm{~Hz}, 1 \mathrm{H})$, $7.17(\mathrm{dt}, J=1.1,7.5 \mathrm{~Hz}, 1 \mathrm{H}), 7.24-7.34(\mathrm{~m}, 3 \mathrm{H}), 7.46(\mathrm{~d}, J=7.9 \mathrm{~Hz}, 1 \mathrm{H}), 7.69$ (dt, $J=1.8,7.9 \mathrm{~Hz}, 1 \mathrm{H})$, $7.90(\mathrm{~d}, J=7.9 \mathrm{~Hz}, 1 \mathrm{H}), 8.71(\mathrm{~d}, J=4.5 \mathrm{~Hz}, 1 \mathrm{H}) ;{ }^{13} \mathrm{C}\left\{{ }^{1} \mathrm{H}\right\} \mathrm{NMR}\left(100 \mathrm{MHz}, \mathrm{CDCl}_{3}\right) \delta 17.7,19.4,72.9$, $122.7,123.2$, 123.8, 125.1, 126.4, 128.4, 128.9, 129.0, 129.2, 130.8, 133.6, 136.1, 136.5, 137.1, 139.5, 149.9, 150.5, 154.4; HRMS (APCI) $m / z\left([\mathrm{M}+\mathrm{H}]^{+}\right)$calcd for $\mathrm{C}_{21} \mathrm{H}_{19} \mathrm{~N}_{2} \mathrm{O}: 315.1492$, found: 315.1493 . The single crystal suitable for $\mathrm{X}$-ray analysis was grown from hexane $/ \mathrm{CH}_{2} \mathrm{Cl}_{2}$.

6-Methyl-2-(pyridin-2-yl)-4-(m-tolyl)-4H-benzo[d][1,3]oxazine (2m) colorless liquid; $12 \mathrm{mg}(38 \%)$; IR (neat, $\mathrm{cm}^{-1}$ ) 1267, 1435, 1492, 1583, 1598, 1625; ${ }^{1} \mathrm{H}$ NMR (400 MHz, CDCl 3 ) $2.22(\mathrm{~s}, 3 \mathrm{H}), 2.25$ (s, 3H), $6.38(\mathrm{~s}, 1 \mathrm{H}), 6.58(\mathrm{~s}, 1 \mathrm{H}), 7.07-7.20(\mathrm{~m}, 5 \mathrm{H}), 7.28(\mathrm{ddd}, J=1.1,4.7,7.6 \mathrm{~Hz}, 1 \mathrm{H}), 7.33(\mathrm{~d}, J=7.9 \mathrm{~Hz}, 1 \mathrm{H})$, 
$7.68(\mathrm{dt}, J=1.7,7.6 \mathrm{~Hz}, 1 \mathrm{H}), 8.04(\mathrm{td}, J=1.0,8.0 \mathrm{~Hz}, 1 \mathrm{H}), 8.69(\mathrm{ddd}, J=1.0,1.7,4.8 \mathrm{~Hz}, 1 \mathrm{H}) ;{ }^{13} \mathrm{C}\left\{{ }^{1} \mathrm{H}\right\}$ NMR $\left(100 \mathrm{MHz}, \mathrm{CDCl}_{3}\right) \delta 21.3,21.5,79.0,123.4,125.0,125.2,125.7,125.8,128.5,128.61,128.62$, $129.7,129.8,136.4,136.6,137.3,138.5,140.0,149.9,150.5,154.7$; HRMS (APCI) $m / z\left([\mathrm{M}+\mathrm{H}]^{+}\right)$calcd for $\mathrm{C}_{21} \mathrm{H}_{19} \mathrm{~N}_{2} \mathrm{O}$ : 315.1492 , found: 315.1490 .

7-(tert-Butyl)-4-(4-(tert-butyl)phenyl)-2-(pyridin-2-yl)-4H-benzo[d][1,3]oxazine (2o) colorless liquid; $11 \mathrm{mg}(28 \%)$ on a $0.10 \mathrm{mmol}$ scale; IR (neat, $\left.\mathrm{cm}^{-1}\right) 1265,1363,1419,1467,1571,1610,1651,1680 ;{ }^{1} \mathrm{H}$ NMR (400 MHz, $\left.\mathrm{CDCl}_{3}\right) \delta 1.29(\mathrm{~s}, 9 \mathrm{H}), 1.34(\mathrm{~s}, 9 \mathrm{H}), 6.50(\mathrm{~s}, 1 \mathrm{H}), 6.80(\mathrm{~d}, J=7.7 \mathrm{~Hz}, 1 \mathrm{H}), 7.21(\mathrm{dd}, J=$ 2.0, $8.0 \mathrm{~Hz}, 1 \mathrm{H}), 7.32-7.38(\mathrm{~m}, 5 \mathrm{H}), 7.57(\mathrm{~d}, J=2.0 \mathrm{~Hz}, 1 \mathrm{H}), 7.76(\mathrm{dt}, J=2.0,7.8 \mathrm{~Hz}, 1 \mathrm{H}), 8.13(\mathrm{td}, J=$ 0.9, $7.8 \mathrm{~Hz}, 1 \mathrm{H}), 8.78(\mathrm{ddd}, J=0.9,1.7,4.7 \mathrm{~Hz}, 1 \mathrm{H}) ;{ }^{13} \mathrm{C}\left\{{ }^{1} \mathrm{H}\right\} \mathrm{NMR}\left(100 \mathrm{MHz}, \mathrm{CDCl}_{3}\right) \delta 31.28,31.30$, $34.6,34.7,78.7,122.4,123.2,123.5,124.2,124.8,125.3,125.6,127.5,136.6,137.1,138.4,150.0,150.5$, 151.8, 152.4, 155.3; HRMS (APCI) $m / z\left([\mathrm{M}+\mathrm{H}]^{+}\right)$calcd for $\mathrm{C}_{27} \mathrm{H}_{31} \mathrm{~N}_{2} \mathrm{O}$ : 399.2431, found: 399.2433 .

4-(Naphthalen-2-yl)-2-(pyridin-2-yl)-4H-naphtho[2,3-d][1,3]oxazine (2q) colorless liquid; $14 \mathrm{mg}$ (37\%); IR (neat, $\mathrm{cm}^{-1}$ ) 1265, 1410, 1440, 1616, 1654, 1685; ${ }^{1} \mathrm{H}$ NMR (400 MHz, $\left.\mathrm{CDCl}_{3}\right) \delta 6.84(\mathrm{~s}, 1 \mathrm{H})$, $7.31(\mathrm{~s}, 1 \mathrm{H}), 7.36-7.41(\mathrm{~m}, 2 \mathrm{H}), 7.45-7.52(\mathrm{~m}, 3 \mathrm{H}), 7.61(\mathrm{dd}, J=1.7,8.4 \mathrm{~Hz}, 1 \mathrm{H}), 7.66(\mathrm{~d}, J=8.1 \mathrm{~Hz}$, 1H), $7.78(\mathrm{dt}, J=1.7,7.7 \mathrm{~Hz}, 1 \mathrm{H}), 7.81-7.90(\mathrm{~m}, 5 \mathrm{H}), 8.00(\mathrm{~s}, 1 \mathrm{H}), 8.21$ (td, $J=1.0,8.0 \mathrm{~Hz}, 1 \mathrm{H}), 8.80$ (ddd, $J=1.0,1.7,4.8 \mathrm{~Hz}, 1 \mathrm{H}) ;{ }^{13} \mathrm{C}\left\{{ }^{1} \mathrm{H}\right\} \mathrm{NMR}\left(100 \mathrm{MHz}, \mathrm{CDCl}_{3}\right) \delta 79.4,123.65,123.68,124.9,125.41$, $125.43,125.6,126.0,126.5,126.6,126.7,127.6,127.7,127.8,128.2,128.3,129.0,132.6,133.0,133.5$, 134.2, 136.66, 136.68, 136.9, 150.0, 150.4, 155.6; HRMS (APCI) $m / z\left([\mathrm{M}+\mathrm{H}]^{+}\right)$calcd for $\mathrm{C}_{27} \mathrm{H}_{19} \mathrm{~N}_{2} \mathrm{O}$ : 387.1492, found: 387.1489 .

(2-Amino-6-methylphenyl)(o-tolyl)methanol (3I) white solid; mp 116.6-118.3 ${ }^{\circ} \mathrm{C} ; 16 \mathrm{mg}(72 \%)$; IR (neat, $\mathrm{cm}^{-1}$ ) 1265, 1357, 1458, 1602, 1710; ${ }^{1} \mathrm{H} \mathrm{NMR}\left(400 \mathrm{MHz}, \mathrm{CDCl}_{3}\right) \delta 2.16(\mathrm{~s}, 3 \mathrm{H}), 2.45(\mathrm{~s}, 3 \mathrm{H}), 6.25$ (s, 1H), 6.59-6.62 (m, 2H), $7.03(\mathrm{t}, J=7.7 \mathrm{~Hz}, 1 \mathrm{H}), 7.10(\mathrm{dt}, J=2.4,6.8 \mathrm{~Hz}, 1 \mathrm{H}), 7.11-7.25(\mathrm{~m}, 3 \mathrm{H})$ : ${ }^{13} \mathrm{C}\left\{{ }^{1} \mathrm{H}\right\}$ NMR $\left(100 \mathrm{MHz}, \mathrm{CDCl}_{3}\right) \delta 19.6,20.0,71.1,116.3,121.2,124.5,126.0,127.0,128.0,128.4$, 131.0, 136.7, 137.3, 138.5, 145.9; HRMS (APCI) $m / z\left([\mathrm{M}+\mathrm{H}]^{+}\right)$calcd for $\mathrm{C}_{15} \mathrm{H}_{18} \mathrm{NO}$ : 228.1383, found: 228.1379. The single crystal suitable for X-ray analysis was grown from hexane $/ \mathrm{CH}_{2} \mathrm{Cl}_{2}$.

\section{ACKNOWLEDGEMENTS}

This work was supported by JSPS KAKENHI Grant Nos. JP 17J00349 (Grant-in-Aid for JSPS Research Fellow) to K.T., JP 15H05485 (Grant-in-Aid for Young Scientists (A)) to K.H., and JP 17 H06092 (Grant-in-Aid for Specially Promoted Research) to M.M. We also thank Dr. Yuji Nishii (Osaka University) for his assistance in obtaining X-ray diffraction data.

\section{REFERENCES AND NOTES}

1. Selected examples: (a) T. Kline, N. H. Andersen, E. A. Harwood, J. Bowman, A. Malanda, S. 
Endsley, A. L. Harris, B. Mendelsohn, K. Mdluli, C. R. H. Raetz, C. K. Stover, P. R. Witte, A. Yabannavar, and S. Zhu, J. Med. Chem., 2002, 45, 3112; (b) H. B. Bode, H. Irschik, S. C. Wenzel, H. Reichenbach, R. Muller, and G. Hofle, J. Nat. Prod., 2003, 66, 1203; (c) M. C. Pirrung, L. N. Tumey, A. L. McClerren, and C. R. H. Ratez, J. Am. Chem. Soc., 2003, 125, 1575; (d) W.-C. Lee, H.-C. Shen, W.-P. Hu, W.-S. Lo, C. Murali, J. K. Vandavasi, and J.-J. Wang, Adv. Synth. Catal., 2012, 354, 2218.

2. Selected examples: (a) K. Kobayashi, Y. Okamura, and H. Konishi, Synthesis, 2009, 1494; (b) Y. Li, Z. Li, T. Xiong, Q. Zhang, and X. Zhang, Org. Lett., 2012, 14, 3522; (c) M. Costa, N. Della Ca, B. Gabriele, C. Massera, G. Salerno, and M. Soliani, J. Org. Chem., 2004, 69, 2469; (d) T. Saito, S. Ogawa, N. Takei, N. Katsumura, and T. Otani, Org. Lett., 2011, 13, 1098; (e) H. Yang, X.-H. Duan, J.-F. Zhao, and L.-N. Guo, Org. Lett., 2015, 17, 1998; (f) S. Jana, A. Ashokan, S. Kumar, A. Verma, and S. Kumar, Org. Biomol. Chem., 2015, 13, 8411.

3. For exceptional successful examples of benzoxazine synthesis from mono-substituted anilines via (formal) aromatic C-H activation, see: (a) T. Xiong, Y. Li, X. Bi, Y. Lv, and Q. Zhang, Angew. Chem. Int. Ed., 2011, 50, 7140; (b) J. Sheng, X. Su, C. Cao, and C. Chen, Org. Chem. Front., 2016, 3,501 .

4. (a) X.-X. Guo, D.-W. Gu, Z. Wu, and W. Zhang, Chem. Rev., 2015, 115, 1622; Related reviews and accounts on $\mathrm{Cu}-$ mediated $\mathrm{C}-\mathrm{H}$ activation: (b) O. Daugulis, H.-Q. Do, and D. Shabashov, Acc. Chem. Res., 2009, 42, 1074; (c) A. A. Kulkarni and O. Daugulis, Synthesis, 2009, 4087; (d) K. Hirano and M. Miura, Chem. Lett., 2015, 44, 868; (e) J. Liu, G. Chen, and Z. Tan, Adv. Synth. Catal., 2016, 358, 1174.

5. (a) K. Takamatsu, K. Hirano, T. Satoh, and M. Miura, Org. Lett., 2014, 16, 2892; (b) K. Takamatsu, K. Hirano, T. Satoh, and M. Miura, J. Org. Chem., 2015, 80, 3242; (c) C. Yamamoto, K. Takamatsu, K. Hirano, and M. Miura, J. Org. Chem., 2016, 81, 7675; (d) C. Yamamoto, K. Takamatsu, K. Hirano, and M. Miura, J. Org. Chem., 2017, 82, 9112.

6. G. He, G. Lu, Z. Guo, P. Liu, and G. Chen, Nat. Chem., 2016, 8, 1131.

7. For seminal work on $N, N$-bidentate coordination strategy in $\mathrm{C}-\mathrm{H}$ activation, see: (a) V. G. Zaitsev, D. Shabashov, and O. Daugulis, J. Am. Chem. Soc., 2005, 127, 13154; Recent reviews: (b) G. Rouquet and N. Chatani, Angew. Chem. Int. Ed., 2013, 52, 11726; (c) L. C. M. Castro and N. Chatani, Chem. Lett., 2015, 44, 410. And ref. 1d.

8. (a) G. A. Ardizzoia, S. Brenna, F. Castelli, S. Galli, and N. Masciocchi, Inorg. Chim. Acta, 2010, 363, 324; (b) G. A. Ardizzoia, S. Brenna, and B. Therrien, Eur. J. Org. Chem., 2010, 3365.

9. M. E. Jung and G. Piizzi, Chem. Rev., 2005, 105, 1735. Similar trends were observed in our previous copper-mediated $\mathrm{C}-\mathrm{H}$ activation; see ref. $5 \mathrm{~b}$. 
10. Crystallographic data for the structures of $\mathbf{2 l}$ and $\mathbf{3 l}$ have been deposited with the Cambridge Crystallographic Data Centre (CCDC 1816027 and 1816028). See the Supporting Information for details.

11. T. Stopka and M. Niggemann, Chem. Commun., 2016, 52, 5761.

12. (a) A. Casitas, M. Canta, M. Solá, M. Costas, and X. Ribas, J. Am. Chem. Soc., 2011, 133, 19386; (b) A. M. Suess, M. Z. Ertem, C. J. Cramer, and S. S. Stahl, J. Am. Chem. Soc., 2013, 135, 9797; (c) L. Liu, M. Zhu, H.-T. Yu, W.-X. Zhang, and Z. Xi, J. Am. Chem. Soc., 2017, 139, 13688.

13. (a) J. Morawiets, W. Sander, and M. Traeubel, J. Org. Chem., 1995, 60, 6368; (b) A. Chrostowska, F. Gracian, J.-M. Sotiropoulos, G. Pfister-Guillouzo, and K. Wojciechowski, Eur. J. Org. Chem., 2000, 313.

14. Actually, the addition of $\mathbf{2 l}(100 \mathrm{~mol} \%)$ decreased the reaction efficiency of $\mathbf{1 a}\left(41 \%{ }^{1} \mathrm{H}\right.$ NMR yield, vs 70\% ${ }^{1} \mathrm{H}$ NMR yield in Scheme 2). The added $2 \mathbf{l}$ was recovered intact in $98 \%$ yield.

15. R. Morioka, K. Hirano, T. Satoh, and M. Miura, Chem. Eur. J., 2014, 20, 12720.

16. Y. Li, R. Wang, T. Wang, X.-F. Cheng, X. Zhou, F. Fei, and X.-S. Wang, Angew. Chem. Int. Ed., 2017, 56, 15436.

17. The deuterium-labeling experiments were performed under the conventional heating conditions with an oil bath, because under microwave-assisted conditions the reaction proceeded in the course of the preheating time up to $180{ }^{\circ} \mathrm{C}$, and the conversion at an early stage was difficult to monitor. Additionally, we confirmed no $\mathrm{H} / \mathrm{D}$ scrambling of $\mathbf{1} \mathbf{j}-\boldsymbol{d}_{\mathbf{1 5}}$ during the course of reaction.

18. S. Pivsa-Art, T. Satoh, Y. Kawamura, M. Miura, and M. Nomura, Bull. Chem. Soc. Jpn., 1998, 71, 467. 